\title{
The oldest known proboscidean and the role of Africa in the radiation of modern orders of placentals
}

\author{
EMMANUEL GHEERBRANT
}

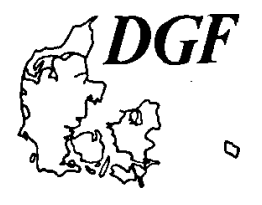

\begin{abstract}
Gheerbrant, E.: The oldest known proboscidean and the role of Africa in the radiation of modern orders of placentals. Bulletin of the Geological Society of Denmark, Vol. 44, pp. 181-185. Copenhagen, 1998-02-28. https://doi.org/10.37570/bgsd-1998-44-12
\end{abstract}

Implications of the discovery of the oldest known proboscidean (Mammalia; Proboscidea) in the late Paleocene of Morocco, Phosphatherium escuilliei, are examined here in an overview of the paleobiogeographical framework of the African mammals. P. escuilliei evidences again the role of Africa in the radiation of modern orders of mammals and the early age of this radiation, which may be related to the extinctions at the K-T boundary. It supports definitely an African origin of the proboscideans, as for primates, hyracoideans, tubulidentates and macroscelideans. It examplifies a much higher antiquity of the African endemism of the placentals than was thought.

Key-words: Africa, Paleogene, radiation, mammals, proboscideans, endemism, Ouled Abdoun Basin.

E. Gheerbrant, Laboratoire de Paléontologie des vertébrés (Case 106), Université Paris 6, 4 place Jussieu, 75252 Paris cédex, France. 18 February 1997.

The Arabo-African continental plate was one of the main centres of mammal evolution at the beginning of the Cenozoic. Because of a poor fossil record, especially compared to Laurasiatic continents, this has long been overlooked. The early Cenozoic mammal record of the Arabo-African continent is indeed one of the poorest with that of Antarctica (two Eocene localities ; Woodburne \& Zinsmeister 1984, Hooker 1992) and Australia (one Eocene locality; Godthelp, Archer, Cifelli, Hand \& Gilkeson 1992). Wide gaps occur in Africa in the Eocene and the Paleocene, and nothing is known for the late Cretaceous.

The discovery of the new proboscidean Phosphatherium escuilliei Gheerbrant, Sudre \& Cappetta 1996 from the Paleocene phosphates of North Africa, from a new locality of the phosphate Ouled Abdoun Basin, Morocco (Fig.1), evidences again the role of Africa in the radiation of modern mammal orders.

\section{The oldest known proboscidean}

Phosphatherium escuilliei documents the oldest and most primitive known proboscidean. It is known from two maxilla fragments preserving most of the jugal dentition (dP4/, P3-4/, M1-2/). The specimens come from the north-eastern part of the Ouled Abdoun Bas- in, from the local phosphate "couche II" which is classically dated as Thanetian (Arambourg 1952). This Thanetian age is supported by the selachian teeth preserved in the matrix of the specimens (Gheerbrant et al. 1996, Gheerbrant, Sudre, Cappetta \& Bignot, in press).

Its jugal upper dentition is characterized by the presence of a small canine, followed by a diastema, three premolars, and three bilophodont molars which increase in size from $\mathrm{M} 1 /$ to $\mathrm{M} 3 /$. Its most conspicuous derived proboscidean features are the loss of $\mathrm{Pl} /$, the developed distocrista and the molars of bilophodont and true lophodont pattern (i.e. presence of two sharp and regular transverse crests, and absence of conules). More generalized features of the tethytheres also occur, such as the orbit in anterior position and the occurrence of an inflated postentoconule which is also known in sirenians. Numidotherium koholense Jaeger 1986 (in Mahboubi, Ameur, Crochet \& Jaeger 1986) from the late Early Eocene locality of El Kohol, Algeria, previously the oldest known proboscidean, has a nearly identical dentition. $P$. escuilliei is therefore included in the same family Numidotheriidae. However, most of their shared features are primitive in proboscideans, possibly except for the absence of a molar lingual cingulum. P. escuilliei differs from $N$. koholense mainly by primitive features. Most strik- 


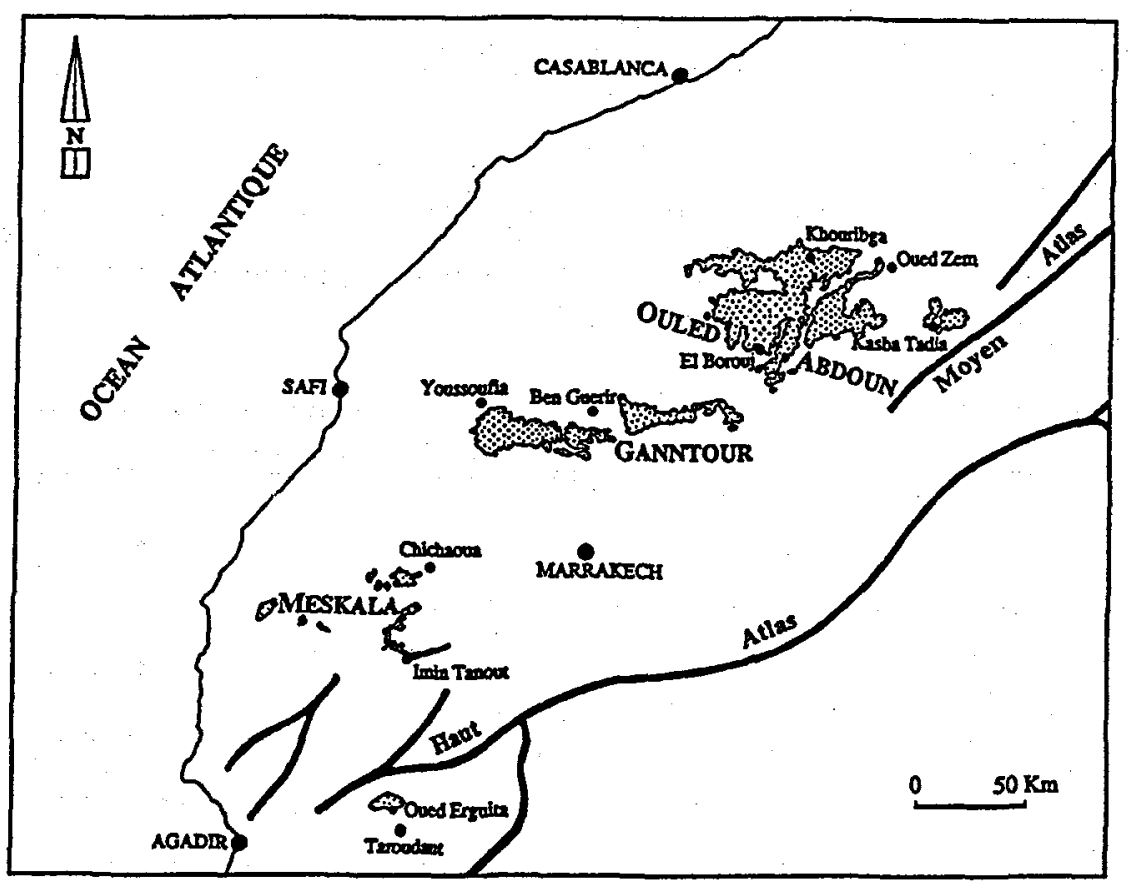

Fig. 1. Location of the Ouled Abdoun Basin, Morocco (Fig. 1 in Noubhani \& Cappetta, 1994). Phosphatherium escuilliei comes from the north-eastern part of the Ouled Abdoun Basin, from the "couche II" of the quarrier terminology which is dated as Thanetian on the basis of its fossil selachian fauna.

ing is its much smaller size; based on allometric scaling of the teeth (Gingerich, Smith \& Rosenberg 1982), its estimated body weight ranges from 10 to 15 kilograms, which corresponds to the smallest known proboscidean. Another striking primitive feature of $P$. escuilliei is the retention of a distinct centrocrista which is linked to an inflated mesostyle. This is a vestige of the dilambdodonty which is generalized in ungulates, known, e.g. in hyracoids, embrithopods, and perissodactyls.

\section{Paleobiogeographical framework and implications of the discovery of \\ Phosphatherium escuilliei}

The discovery of a Paleocene proboscidean from the Arabo-African continent has several implications of broad interest for mammals. It ranks among the few known fossil occurrences of modern orders of mammals in pre-Eocene strata. Of the 18 extant placental orders, only 7 were previously recorded before the Eocene: the edentates (palaeanodonts), the lipotyphlans (especially nyctitheriids), the carnivorans (viverravids), the lagomorphs (mimotonids), the rodents (ischyromyids, eurymylids), the primates (Altiatlasius), and perhaps the dermopterans if plesiadapiforms really belong to this order. Actually, $P$. escuilliei is the oldest known modern ungulate, and the first one recorded from the Paleocene. According to current phylogenetic studies (e.g. Novacek 1992, 1993),
Proboscidea is among the most derived placental orders. The discovery of a Paleocene proboscidean is indeed the first direct evidence of the early age of the radiation of modern orders of placentals, which must be earlier than the late Paleocene. The radiation must also have been very rapid, with an "explosive" pattern, if it is closely correlative to the extinction events at the end of the Cretaceous.

$P$. escuilliei emphasizes the ancient origin of the proboscideans of the Arabo-African continent and the antiquity of the placental population on the continent. The early presence of placentals on the continent was already suggested by the diversified Thanetian Adrar Mgorn fauna from the Ouarzazate Basin, Morocco (Gheerbrant 1990), which is the only other known Paleocene mammal fauna from the Arabo-African continent. It was also suggested by the diversity and the strongly endemic character of later Paleogene African mammal faunas. The endemism is still noticeable in extant African mammal faunas with the occurrence of peculiar taxa such as potamogales (tenrecids), golden moles (chrysochlorids), elephantshrews (macroscelideans), aardvarks (tubulidentates), hyraxes (hyracoideans), and the thryonomyid and anomalurid rodent families. However, it is during Paleogene time that the endemism of the mammals on the Arabo-African continent culminates. Among the known fossils, the then native mammals are strongly predominant. They belong to several lineages of extant taxa (Fig. 2): some, such as the primates and the proboscideans, are known as early as the late Paleocene; others, such as the macroscelideans, 
Fig. 2. Temporal distribution of the mammal orders in the Arabo-African continent. For each order, the probable episodes of immigration in the Arabo-African continent are indicated by arrows (I). Discontinuous lines indicate uncertain fossil record. Paleogene localities: 1. Adrar Mgorn (Morocco), Ouled Abdoun (Morocco); 2. N'Tagourt 2 (Morocco); 3. El Kohol (Algeria), Chambi (Tunisia), Gour Lazib and Glib Zegdou (Algeria); 4. M'Bodione Dadere (Senegal), In Tafidet (Mali), Tamaguilelt (Mali), Kpogamé-Hahotoé (Togo); 5. Bir El Ater (Algeria), Dor El Talha (Evaporite Unit, Libya), Fayum (Qasr El Sagha Fm, Egypt); 6. Dor El Talha (Idam Unit, Libya), Fayum (Jebel Qatrani Fm, Egypt), Zella (Libya), Jebel Hasawnah (Libya), Taqah and Thaytiniti (Oman), Malembe (Angola), Jebel Bou Gobrine (Tunisia), Oued Bazina (Tunisia), Bled Mellaha (Tunisia).

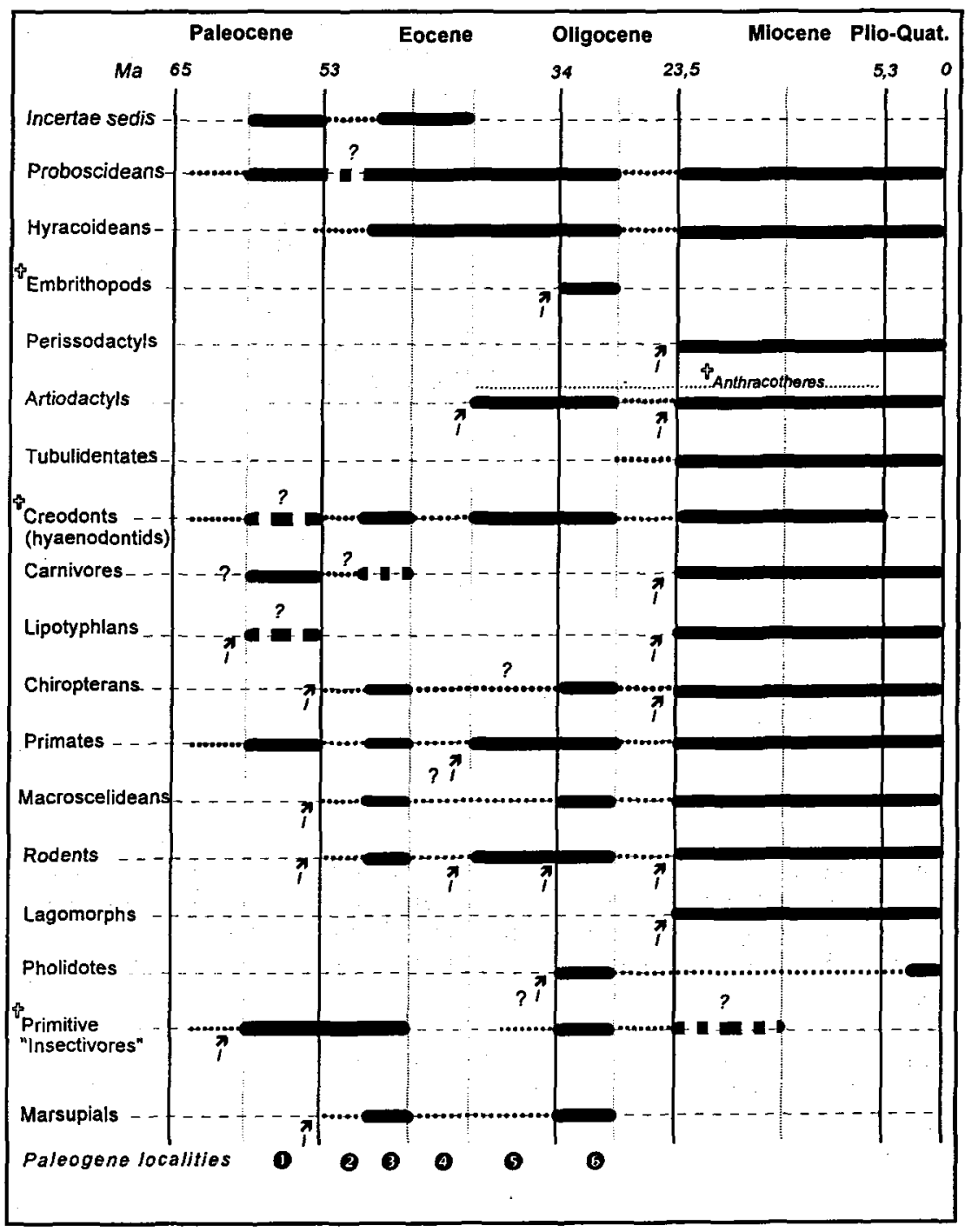

the first rhinolophoid and vespertilionoid chiropterans, the hyracoideans and the zegdoumyid rodents (considered as ancestral to the extant anomalurids by Vianey-Liaud et al. 1994), are known since the late early Eocene; and still others, such as the phiomyid rodents (presumed to be ancestral to extant thryonomyids), are known from the late Eocene. There are several other modern mammal taxa which possibly or probably originated on the Arabo-African continent in Paleogene times (Fig. 3). Such is the case for the aardvark order (tubulidentates) and for the lipotyphlan families of golden moles (chrysochlorids) and potamogales (tenrecids), though none of them has a known fossil record before the Miocene. Sirenians are also sometimes considered of African origin; they beIong to the super-group Paenungulata, together with proboscideans and hyracoideans, both African. Moreover, the phiomorph rodents and the parapithecid pri- mates from the Paleogene of Africa are the most likely ancestors of, respectively, the caviomorph rodents and the platyrrhine primates of South America. Finally, Gingerich (1986) has advanced the hypothesis of an African origin of flourishing Laurasiatic groups such as the adapiform and omomyiform primates, the hyaenodontid creodonts, the artiodactyls and the perissodactyls. Among them, artiodactyls and perissodactyls are major components of the extant herbivorous mammal fauna.The sudden appearance of these groups in Laurasiatic continents at the beginningof the Eocene suggests indeed their immigration from a poorly known south-Tethyan continent such as Africa.

As a taphonomic bias, the Adrar Mgorn locality has not yielded large mammals such as ungulates. With $P$. escuilliei, the Ouled Abdoun Basin has produced the first representative of an order of large mammals from the Paleocene of the Arabo-African continent. It thus 


\begin{tabular}{|c|}
\hline \multicolumn{1}{|c|}{ Modern taxa } \\
\hline - Native African taxa with Paleogene fossil record \\
- Order Proboscidea* \\
- Order Hyracoidea* \\
- Order Primates \\
- Order Macroscelidea \\
- ? Order Sirenia* \\
- Vespertilionoid and rhinolophoid chiropterans \\
- Anomalurid and thryonomyid rodents, as presumed descendants \\
of zegdoumyids and phiomyids, respectively \\
- Order Tubulidentata \\
- Chrysochlorid lipotyphlans \\
- Tenrecid lipotyphlans (at least potamogales) \\
\hline - Endemic African taxa unknown before the Miocene \\
- ? Order Artiodactyla \\
- ? Order Perissodactyla \\
- Caviomorph rodents, as descendants of African phiomorphs \\
- Platyrrhine primates, as descendants of African parapithecids \\
\hline - Extinct taxa \\
(Pantolesta ?) and Helioseus (Eutheria incertae sedis) \\
\hline Taxa from Laurasia unknown before the Eocene \\
\hline - South American taxa unknown before the Oligocene \\
\hline
\end{tabular}

? : taxa of hypothetical Arabo-African origin (with no definitive fossil evidence), known outside the continent. *taxa of the supergroup Paenungulata.
Fig. 3. Summary of the main mammal taxa of probable or possible Arabo-African Paleogene origin. exemplifies the first taphonomical, stratigraphical and paleogeographical context in which the hypothesis of an African origin of the artiodactyls and the perissodactyls may be tested. On the other hand, the Adrar Mgorn locality supports the hypothesis of the African origin of the Primates with the discovery of Altiatlasius koulchii Sigé 1990 (in Sigé, Jaeger, Sudre \& VianeyLiaud 1990), whatever be its exact systematic position (omomyiform according to Sigé et al. 1990; protosimiiform according to Godinot 1994), and possibly also of the hyaenodontid creodonts (Gheerbrant 1995), which are well developed in later African faunas.

This overview of the available paleobiogeographical data shows that the role of the Arabo-African continent in the radiation of modern mammals, especially at ordinal level, can no more be dismissed. The continent appears to be the source of five to eight extant placental orders (Fig. 3). This is all the more significant as its known Paleogene fossil record is much more incomplete than that of the Laurasiatic continents.
Moreover, the number of modern high taxa originating in Arabo-Africa appears to be substantial with respect to other south-Tethyan continents, such as South America. This may be related to its less complete isolation during the Cenozoic.

In contrast to the strong Laurasian affinities of the Adrar Mgorn fauna, the proboscidean from the Ouled Abdoun Basin evidences a high age of the African endemism, of still unknown beginning. The dawn of the history of the placentals on the Arabo-African continent is still unknown.

\section{Dansk sammendrag}

Den ældste kendte proboscidie (orden Proboscidea; i nutiden repræsenteret ved familien Elephantidae, elefanterne), Phosphatherium escuilliei Gheerbrant, Sudre \& Capetta 1996, er fundet i aflejringer fra sen Paleocæn i Marokko. Her unders $\varnothing$ ges implikationerne af dette fund $i$ en palæobiogeografisk oversigt over 
pattedyrene på Det arabo-afrikanske Kontinent. $P$. escuilliei er endnu et tegn på, at Afrika spillede en rolle i udviklingen af de moderne pattedyrordner, og at denne udvikling foregik tidligt $\mathrm{i}$ tertiær, muligvis med relation til den store uddøen ved Kridt/tertiærgrænsen. Fundet viser, at proboscidierne, og dermed elefanterne, er af afrikansk oprindelse, ligesom primaterne (orden Primates), klippegrævlingerne (orden Hyracoidea), jordsvinene (orden Tubulidentata) og springspidsmusene (orden Macroscelidea). De placentale pattedyr i Afrika er karakteriseret ved en høj grad af endemisme, og med $P$. escuilliei kan endemismen følges længere tilbage i tiden, end det hidtil har været muligt.

\section{References}

Arambourg, C. 1952: Vertébrés fossiles des Phosphates d'Afrique du Nord (Maroc, Algérie, Tunisie). Notes et Mémoires du Service Géologique du Maroc (Rabat), 92, 1-372.

Gheerbrant, E. 1990: On the early biogeographical history of the African placentals. Historical Biology 4, 107-116.

Gheerbrant, E. 1995: Les mammifères paléocènes du Bassin d'Ouarzazate (Maroc). III. Adapisoriculidae et autres mammifères (Carnivora, ?Creodonta, Condylarthra, ?Ungulata et incertae sedis). Palaeontographica A237, $1-4,39-132$.

Gheerbrant, E., Sudre, J. \& Capetta, H. 1996: A Palaeocene proboscidean from Morocco. Nature 383, 68-71.

Gheerbrant, E., Sudre, J., Capetta H. \& Bignot, G. (in press): Phosphatherium escuilliei des phosphates thanétiens du Bassin des Ouled Abdoun (Maroc), le plus ancien proboscidien (Mammalia) d'Afrique. Geobios.

Gingerich, P. D. 1986: Early Eocene Cantius torresi-oldest Primate of modern aspect from North America. Nature 319, 319-321.

Gingerich, P. D., Smith, B. H. \& Rosenberg, K. 1982: Allometric scaling in the dentition of primates and prediction of body size from tooth size in fossils. American Journal of Physical Anthropology 58, 81-100.

Godinot, M. 1994: Early north African primates and their significance for the origin of Simiiformes (= Anthropoidea). In Fleagle J. G. \& Kay R. (eds) Anthropoid Origins, 235-295. Plenum Press, New York.

Godthelp, H., Archer, M., Cifelli, R., Hand, S. J. \& Gilkeson, C. F. 1992: Earliest known Australian Tertiary mammal fauna. Nature $356,514-516$.

Hooker, J. J. 1992: An additional record of a placental mammal (Order Astrapotheria) from the Eocene of West Antarctica. Antarctic Science 4, 107-108.

Mahboubi, M., Ameur, R., Crochet, J.-Y. \& Jaeger, J.-J. 1986: El Kohol (Saharan Atlas, Algeria): A new Eocene mammal locality in North Western Africa. Palaeontographica 192, 15-49.

Noubhani, A. \& Capetta, H. 1994: Revision des Rhombodontidae (Neoselachii, Batomorphii) des Bassins à Phosphate du Maroc. Palaeovertebrata 23, 1-49.

Novacek, M. J. 1992: Mammalian phylogeny: Shaking the tree. Nature 356, 121-125.
Novacek, M. J. 1993: Reflections on higher mammalian phylogenetics. Journal of Mammalian Evolution, 1 130.

Sige, B., Jaeger, J.-J., Sudre, J. \& Vianey-Liaud, M. 1990: Altiatlasius koulchii n. gen., n.sp. primate omomyidé du Paléocène supérieur du Maroc, et les origines des euprimates. Palaeontographica A214, 31-56.

Vianey-Liaud, M., Jaeger, J.-J., Hartenberger, J.-L. \& Mahboubi, M. 1994: Les rongeurs de l'Eocène d'Afrique Nord-Occidentale [Glib Zegdou (Algérie) et Chambi (Tunisie)] et l'origine des Anomaluridae. Palaeovertebrata 23, 93-118.

Woodburne, M. O. \& Zinsmeister, W. J. 1984: The first land mammal from Antarctica and its biogeographic implications. Journal of Paleontology 58, 913-948. 